\title{
Penyerahan Sertifikat kepada Pengadilan oleh Penyidik sebagai Aset Sitaan yang Berimplikasi Tindak Pidana Penggelapan dalam Jabatan
}

\author{
Investigator Land Certificate Consignment to the Court as Confiscated Asset \\ Implicated Employment Embezzlement Crime
}

\author{
Safaruddin \\ Kepolisian Negara Republik Indonesia \\ E-mail: IndonesiaSafar6449@gmail.com \\ Handrawan \\ Pascasarjana Universitas Halu Oleo \\ E-mail: handrawansaranani84@gmail.com \\ Oheo K. Haris \\ Pascasarjana Universitas Halu Oleo \\ E-mail: oheokh@gmail.com
}

\begin{abstract}
This paper addressed analyzing on handover of land certificate by investigator to the court implicated duty crime. And it is analyzing the legal protection for investigator who run the function of confiscation of land certificate into the court. This study applied legislation, concepts, and case approach. This research answered the question that handover of land certificate is considered at asset foreclosure that is able impacted crime in term of duty matters. In this criminal provision context that the elements of willing and knowing (willen en wetens) are part of intention toward the fault which is considered not able be guilty. This argument stated on article 415 and 374 Indonesia Penal Code. Besides, it is also did not qualified the elements of misuse power that is prejudicial another person. This is due to handover of land certificate to the court based on registered letter: W23.UI/1080/HT/VI/2017 concerning court commandment for investigator toward handover of land certificate.
\end{abstract}

Keyword: Handover; Assets; Court

Abstrak: Tulisan ditujukan untuk menganalisis perintah penyerahan sertifikat kepada penyidik oleh pengadilan dapat berimplikasi sebagai tindak pidana penggelapan dalam jabatan. Dan menganalisis perlindungan yang berkepastian hukum bagi penyidik dalam pelaksanaan tugas dan wewenangnya dalam penyitaan atas tindakan penyerahan sertifikat sitaan ke pengadilan. Penelitian ini menggunakan Pendekatan perundangundangan, konsep hukum Pidana, dan Pendekatan Kasus. Hasil studi ini menjawab rumusan masalah bahwa penyerahan sertifikat sebagai aset sitaan penyidik kepada pengadilan yang berimplikasi sebagai tindak pidana penggelapan dalam jabatan bukan 
sebagai tindak pidana. Dalam konteks teori hukum unsur mengetahui dan menghendaki (willens en wetens) sebagai unsur kesengajaan atas kesalahan tidak terpenuhi sehingga tidak dapat dimintakan pertanggungjawaban pidana. Dalam Konteks aturan hukum Pasal 415 KUHP dan Pasal 374 KUHP juga tidak terpenuhi unsur objektif dari penggelapan yakni unsur menyalahgunakan jabatan yang merugikan orang lain karena penyerahan sertifikat kepada pengadilan sesuai dengan Surat Nomor: W23.UI/1080/HT/VI/2017 Perihal tindak lanjut penyelesaian pelaksanaan putusan eksekusi memerintahkan penyidik untuk menyerahkan sertifikat tersebut kepada pengadilan.

Kata kunci: Penyerahan Sertifikat; Aset Sitaan; Pengadilan

\section{PENDAHULUAN}

Penyitaan merupakan tindakan paksa yang dilegitimasi (dibenarkan) oleh undang-undang atau dihalalkan oleh hukum, namun dalam melakukan penyitaan penyidik tidak sembarangan menyita barang tanpa aturan main yang telah digariskan oleh peraturan perundang-undangan, penyidik harus patuh terhadap ketentuan KUHAP. Pasal 38 ayat (1) KUHAP menjelaskan penyitaan hanya dapat dilakukan oleh penyidik dengan surat izin ketua pengadilan negeri setempat. Pasal 38 ayat (2) KUHAP yang berbunyi: “dalam keadaan yang sangat perlu dan mendesak bilamana penyidik harus segera bertindak dan tidak mungkin untuk mendapatkan surat izin terlebih dahulu, tanpa mengurangi ketentuan ayat (1) penyidik dapat melakukan penyitaan hanya atas benda bergerak dan untuk itu wajib segera melaporkan kepada ketua pengadilan negeri setempat guna memperoleh persetujuannya". Pemberian izin penyitaan oleh ketua pengadilan negeri artinya memberikan pengesahan atau atas tindakan penyidik dalam mengumpulkan barang bukti terkait dengan suatu tindak pidana1.

Ketentuan Pasal 128 KUHAP, juga telah menjelaskan hal yang harus dilakukan penyidik pada saat ingin melakukan penyitaan yaitu terlebih dahulu menunjukkan tanda pengenalnya kepada orang dari mana benda itu disita. Dan dalam Pasal 129 KUHAP, penyidik juga harus memperlihatkan benda yang akan disita atau kepada keluarganya dapat dimintai keterangan tentang benda yang akan disita, yang disaksikan oleh Kepala Desa atau ketua lingkungan yang dihadiri oleh dua orang saksi. Untuk selanjutnya penyidik membuat berita acara penyitaan yang dibacakan terlebih dahulu kepada orang dari mana benda itu disita atau keluarganya dengan diberi tanggal dan ditandatangani oleh penyidik maupun orang tua atau keluarganya. dan untuk benda sitaan sebelum dibungkus, dicatat berat dan atau jumlah menurut jenis masing-masing, ciri maupun sifat khas, tempat, hari dan tanggal penyitaan, identitas orang dari mana benda itu

1 Sumaidi, “Kajian Terhadap Penyitaan Sebagai Pemaksaan yang Dihalalkan oleh Hukum”, Jurnal Legaliatas: Jurnal Hukum. Vol. 8 Nomor 1 Tahun 2016, hlm. 220-244. 
disita yang kemudian diberi cap jabatan atau ditandatangani oleh penyidik. terkait dengan benda sitaan yang tidak dimungkinkan untuk dibungkus, penyidik memberi catatan yang ditulis di atas label yang ditempelkan dan atau dikaitkan pada benda tersebut sebagaimana diatur dalam Pasal 130 KUHAP.

Uraian di atas merupakan konstruksi normatif tujuan dan prosedur formal pelaksanaan penyitaan. Dalam konstruksi empiris penyitaan yang menjadi kewenangan normatif penyidik sering di benturkan dengan tuduhan dengan dugaan tindak pidana dalam jabatan dan/atau penggelapan dalam jabatan sebagaimana dimaksud dalam Pasal 415 Kitab Undang-undang Hukum Pidana ${ }^{2}$ dan Pasal 374 Kitab Undang-Undang Hukum Pidana ${ }^{3}$ (selanjutnya disebut KUHP) .

Deskripsi awal keadaan empiris yang dihadapi penyidik dalam hal ini penyidik POLRI adalah adanya laporan oleh pemilik sertifikat ke Kepolisian Daerah Sulawesi Tenggara (selanjutnya disebut POLDA SULTRA) dengan Nomor Polisi LP/303/VII/2017/SPKT POLDA SULTRA tanggal 14 Juli 2017 dengan terlapor para penyidik Satuan Reserse Kriminal Kepolisian Resort Kendari (selanjutnya disebut Satreskrim Polres Kendari) dan Ombudsman dengan dugaan tindak pidana dalam jabatan dan/atau penggelapan dalam jabatan karena penyidik menyerahkan sertifikat yang di yang dalam kekuasaannya dimana diperoleh melalui penyitaan dari pemilik sertifikat ke peda pengadilan tanpa persetujuan dan izin dari pemilik sertifikat.

Penyitaan sertifikat dari pemilik didasarkan adanya laporan dugaan penipuan dan penggelapan yang dilakukan oleh pemilik sertifikat dan berdasarkan penilaian dari hasil penyidikan dianggap perlu bagi penyidik menurut undang-undang untuk melakukan penyitaan atas objek sertifikat tersebut. Namun karena pertimbangan tertentu pelapor menarik laporannya terhadap pemilik sertifikat dan kemudian diterbitkan SP3. Alasan pencabutan laporan maka penyidik Satrekrim Polres Kendari meminta kepada ketua pengadilan Kendari Melalui surat nomor: B/425/VI/2017 Reskrim Kendari tanggal 9 Juni 2017 perihal pencabutan penetapan penyitaan barang bukti. Namun Pengadilan berdasarkan Perintah pengadilan melalui Surat Nomor: W23.UI/1080/HT/VI/2017 Perihal tindak lanjut penyelesaian

2 Pasal 415 KUHP: Pegawai negeri atau orang lain, yang diwajibkan untuk seterusnya atau untuk sementara waktu menjalankan sesuatu pekerjaan umum, yang dengan sengaja menggelapkan uang atau surat yang berharga, yang disimpannya karena jabatannya, atau dengan sengaja membiarkan uang atau surat yang berharga itu diambil atau digelapkan oleh orang lain atau menolong orang yang lain itu sebagai orang yang membantu dalam $\mathrm{h}$ itu dihukum penjara selama-lamanya tujuh tahun.

3 Pasal 374 KUHP: Penggelapan yang dilakukan oleh orang yang penguasaannya terhadap barang disebabkan karena ada hubungan kerja atau karena pencarian atau karena mendapat upah untuk itu, diancam dengan pidana penjara paling lama lima tahun. 
pelaksanaan putusan eksekusi memerintahkan penyidik untuk menyerahkan sertifikat tersebut kepada pengadilan, dan dengan alasan undang-undang dimana penyidik tunduk terhadap perintah dan putusan pengadilan kemudian menyerahkan objek sertifikat tersebut kepada pengadilan untuk dieksekusi. Kebebasan atas perintah dalam putusan hakim merupakan mahkota yang harus dikawal dan dihormati oleh masyarakat dan penegak hukum ${ }^{4}$ Penyerahan sertifikat merupakan suatu keharusan yang wajib ditaati oleh penyidik dalam konsepsi teori hukum. Teori hukum merupakan kaidah hukum suatu putusan yang idealnya harus memenuhi ketiga macam unsur yaitu: landasan yuridis, sosiologis, dan filosofis 5 . Perintah penyerahan sertifikat kepada pengadilan karena pemilik sertifikat kalah dalam gugatan perdata. Lebih lanjut penulis menjelaskan bahwa perkara ini adalah perkara yang dimulai dari sengketa yang bersifat privat/perdata yang berujung pada perkara pidana yang kemudian perkara tersebut berstatus SP3. Berdasarkan Uraian latar belakang tersebut di atas mendorong penulis tertarik untuk melakukan penelitian dengan judul "Penyerahan Sertifikat Sebagai Aset Sitaan Kepada pengadilan". Berdasarkan uraian fakta hukum di atas maka Isu hukum yang akan di rumuskan penulis dalam penelitian ini yakni apakah penyerahan sertifikat sebagai asetsitaan penyidik kepada pengadilan dapat dipidana sebagai tindak pidana penggelapan dalam jabatan. Selain itu juga membahas bagaimanakah perlindungan yang berkepastian hukum bagi penyidik dalam pelaksanaan tugas dan wewenangnya dalam penyitaan atas tindakan penyerahan sertifikat sitaan ke pengadilan?

\section{METODE PENELITIAN}

Penelitian ini menggunakan tipe penelitian hukum yaitu penelitian yang didasarkan pada pengkajian atas ketentuan peraturan perundang-undangan yang berlaku terkait dengan Penyerahan Sertifikat Sebagai Aset Sitaan Penyidik Kepada Pengadilan. Pendekatan undangundang (statute aprroach) , yaitu untuk menelaah semua peraturan perundang-undangan yang terkait Penyerahan Sertifikat Sebagai Aset Sitaan Penyidik Kepada Pengadilan, Pendekatan kasus (case approach) adalah pendekatan dilakukan untuk menelaah kasus Penyerahan Sertifikat Sebagai Aset Sitaan Penyidik Kepada Pengadilan dan Pendekatan konseptual (conseptual approach) adalah pendekatan dengan menggunakan teori, pendapat dan doktrin hukum terkait dengan Penyerahan Sertifikat Sebagai Aset Sitaan Penyidik Kepada Pengadilan.

\footnotetext{
4 Handrawan, Pencabutan Hak Politik dalam Pemidanaan Tindak Pidana Korupsi, Surabaya: Media Sahabat Cendekia, 2019, hlm. 194.

5 Oheo K. Haris, "Telaah Yuridis Penerapan Sanksi di Bawah Minimum Khusus pada Perkara Pidana Khusus", Jurnal Ius Constituendum, Volume 2, Nomor 2, 2017, hlm. 247.
} 


\section{ANALISIS DAN PEMBAHASAN}

Penyerahan Sertifikat sebagai Aset Sitaan Penyidik kepada Pengadilan Tidak Dapat Dipidana Sebagai Tindak Pidana Penggelapan dalam Jabatan

Penyitaan sertifikat dari pemilik didasarkan adanya laporan dugaan penipuan dan penggelapan yang dilakukan oleh pemilik sertifikat dan berdasarkan penilaian dari hasil penyidikan dianggap perlu bagi penyidik menurut undang-undang untuk melakukan penyitaan atas objek sertifikat tersebut. Namun karena pertimbangan tertentu pelapor menarik laporannya terhadap pemilik sertifikat dan kemudian diterbitkan SP3. Alasan pencabutan laporan maka penyidik Satrekrim Polres Kendari meminta kepada ketua pengadilan Kendari Melalui surat nomor: B/425/VI/2017 Reskrim Kendari tanggal 9 Juni 2017 perihal pencabutan penetapan penyitaan barang bukti. Namun Pengadilan berdasarkan Perintah pengadilan melalui Surat Nomor: W23.UI/1080/HT/VI/2017 Perihal tindak lanjut penyelesaian pelaksanaan putusan eksekusi memerintahkan penyidik untuk menyerahkan sertifikat tersebut kepada pengadilan, dan dengan alasan undang-undang dimana penyidik tunduk terhadap perintah dan putusan pengadilan kemudian menyerahkan objek sertifikat tersebut kepada pengadilan untuk dieksekusi. Kebebasan atas perintah dalam putusan hakim merupakan mahkota yang harus dikawal dan dihormati oleh masyarakat dan penegak hukum ${ }^{6}$. Penyerahan sertifikat merupakan suatu keharusan yang wajib ditaati oleh penyidik dalam konsepsi teori hukum.

Teori hukum merupakan kaidah hukum suatu putusan yang idealnya harus memenuhi ketiga macam unsur yaitu: landasan yuridis, sosiologis, dan filosofis ${ }^{7}$. Perintah penyerahan sertifikat kepada pengadilan karena pemilik sertifikatkalah dalam gugatan perdata. Lebih lanjut penulis menjelaskan bahwa perkara ini adalah perkara yang dimulai dari sengketa yang bersifat privat/perdata yang berujung pada perkara pidana yang kemudian perkara tersebut berstatus SP3.

Jika mengacu pada konstruksi Pasal 374 KUHP yang berbunyi, Penggelapan yang dilakukan oleh orang yang penguasaannya terhadap barang disebabkan karena ada hubungan kerja atau karena pencarian atau karena mendapat upah untuk itu, diancam dengan pidana penjara paling lama lima tahun dan Pasal 415 KUHP berbunyi, Pegawai negeri atau orang lain, yang diwajibkan untuk seterusnya atau untuk sementara waktu menjalankan sesuatu pekerjaan umum, yang dengan sengaja menggelapkan uang atau surat yang berharga, yang disimpannya karena jabatannya, atau dengan sengaja membiarkan uang atau surat yang 
berharga itu diambil atau digelapkan oleh orang lain atau menolong orang yang lain itu sebagai orang yang membantu dalam hal itu dihukum penjara selama-lamanya tujuh tahun. Terdapat 2 unsur yang terdapat dalam ketentuan pasal 415 KUHP yakni unsur subyektif dan unsur obyektif. Unsur subyektif tersebut di dalam hukum pidana meliputi pegawai negeri, dan orang lain dan unsur obyektif terkait dengan perbuatan yang meliputi, unsur menjalankan pekerjaan, sengaja penggelapan uang dan surat, karena jabatannya, di gelapkan oleh orang lain atau menolong orang lain sebagai membantu.

Dalam konstruksi pasal di atas jelas bahwa tindakan dan perbuatan penyidik reskrim Kendari yang menyerahkan sertifikat sitaan kepada pengadilan tidak memenuhi unsur pasal 415 KUHP yakni unsur penggelapan yang dapat memberikan keuntungan bagi pihak yang menggelapkan maupun orang lain. Secara teoritis penggelapan memiliki definisi" bahwa suatu barang yang menjadi objek tindak pidana ada dalam kekuasaan pelaku secara sah dan barang yang dikuasai tersebut karena tugas jabatannya sebagaimana yang dimaksud dalam pasal 372 KUHP yang berbunyi, barang siapa dengan sengaja memiliki dengan melawan hukum suatu barang yang seluruhnya atau sebagian kepunyaan orang lain dan barang itu sudah ada ditangan bukan karena kejahatan. Dalam ajaran hukum pidana apabila salah satu unsur tidak terpenuhi maka seseorang tidak dapat dituntut dengan pasal tersebut. Ketentuan tersebut mengandung makna bahwa tak seorang pun dapat dipersalahkan dan atau memenuhi unsur kesalahan yang diketahui dan atau dikehendakinya apabila tidak memenuhi salah satu unsur pasal yang ditentukan kepadanya.

Menurut Simons Kesalahan adalah terdapatnya keadaan psikis tertentu pada seseorang yang melakukan tindak pidana dan adanya hubungan antara keadaan tersebut dengan perbuatan yang dilakukan, yang sedemikian rupa hingga orang itu dapat dicela karena melakukan perbuatan tadi ${ }^{8}$. Menurut Mezger Kesalahan merupakan suatu keadaan psikologis yang oleh penilaian hukum pidana ditentukan sebagai perbuatan yang keliru dan dapat dicela9

Dalam konstruksi teori penulis merujuk pada asas hukum pidana yakni tidak ada pidana tanpa kesalahan" (Geen straf zonder schuld) dengan demikian harus ada 2 unsur untuk adanya pertanggungjawaban pidana: (1) ada tindak pidana; dan (2) ada kesalahan. Menurut Roscoe Pound, pertanggungjawaban pidana adalah sebagai suatu kewajiban untuk membayar pembalasan yang akan di terima pelaku dari seseorang yang telah dirugikan. Saya sendiri mengartikan Pertanggungjawaban pidana adalah dapat dipertanggungjawabkannya perbuatan

Teguh Prasetyo, Hukum Pidana, Jakarta: RajaGrafindo Persada, 2014, hlm. 79.

9 Bambang Purnomo, Asas-Asas Hukum Pidana, Yogyakarta: Ghia Indonesia, 1994, hlm. 138. 
melanggar ketentuan undang-undang dengan sanksi pidana terhadap pelakunya. Selain itu penulis merujuk pada asas tiada pidana tanpa kesalahan dalam perundang-undangan di Indonesia terdapat dalam Pasal 6 ayat (1) Undang-Undang RI Nomor 48 Tahun 2009 tentang Kekuasaan Kehakiman bahwa "Tidak seorang pun dapat dijatuhi pidana, kecuali apabila pengadilan karena alat pembuktian yang sah menurut undang-undang, mendapat keyakinan bahwa seseorang yang dianggap dapat bertanggung jawab, telah bersalah atas perbuatan yang didakwakan atas dirinya.

Selain itu menurut penulis terdapat adagium yang mengatakan bahwa "Actus non facit reum, nisi mens sit rea" yang artinya "perbuatan tidak membuat orang bersalah, terkecuali jika terdapat sikap batin yang jahat". dari adagium tersebut dapat dikatakan bahwa untuk mengetahui adanya kesalahan pelaku tindak pidana itu ada pada Sikap batinnya (mens rea) . jadi jika perbuatan orang (actus reus) yang memenuhi unsur-unsur delik (tindak pidana) merupakan unsur obyektif, maka sikap batin orang tersebut (mens rea) merupakan unsur subyektifnya. walaupun kesalahan merupakan unsur yang menentukan dapat tidaknya orang dipidana, namun unsur-unsur tindak pidana haruslah terlebih dahulu dipenuhi, baru kemudian dilihat unsur kesalahannya sehingga terdapat pertanggungjawaban pidana.

Dalam menilai unsur kesalah atas tindakan penyerahan sertifikat oleh penyidik kepada pengadilan apakah sebagai tindak pidana dalam jabatan atau tidak maka penulis merujuk pada M.v.T. (Memorie van Toelichting) , yaitu "Pidana pada umumnya hendaknya dijatuhkan hanya pada barang siapa melakukan perbuatan yang dilarang, dengan dikehendaki dan diketahui". Dalam pengertian ini disebutkan bahwa kesengajaan diartikan sebagai: "menghendaki dan mengetahui" (willens en wetens). Artinya, seseorang yang melakukan suatu tindakan dengan sengaja, harus menghendaki serta menginsafi tindakan tersebut dan/atau akibatnya. Jadi dapatlah dikatakan, bahwa sengaja berarti menghendaki dan mengetahui apa yang dilakukan. Orang yang melakukan perbuatan dengan sengaja menghendaki perbuatan itu dan di samping itu mengetahui atau menyadari tentang apa yang dilakukan itu dan akibat yang akan timbul dari padanya.

Kedua konstruksi teori dan asas di atas jelas mengandung makna bahwa tindakan penyerahan sertifikat yang dilakukan penyidik Reskrim Polres Kendari ke pengadilan bukanlah perbuatan yang dapat memenuhi unsur pertanggungjawaban pidana dan kesalahan sebab penyerahan sertifikat tersebut telah memenuhi ketentuan dalam ajaran teori hukum yakni:

1. Sertifikat yang ada dalam kekuasaan penyidik adalah objek eksekusi yang telah berkekuatan hukum tetap dan yang menguasai sertifikat tersebut telah kalah dalam 
sidang perdata yang telah inkrah;

2. Penyerahan sertifikat tersebut karena perintah undang-undang yakni dengan adanya Perintah pengadilan melalui Surat Nomor: W23.UI/1080/HT/VI/2017 Perihal tindak lanjut penyelesaian pelaksanaan putusan eksekusi memerintahkan penyidik untuk menyerahkan sertifikat tersebut kepada Pengadilan;

3. Tidak terdapat unsur yang menguntungkan bagi penyidik maupun orang lain dengan adanya tindakan penyerahan sertifikat tersebut ke Pengadilan;

4. Mekanisme penghentian dan penerbitan SP3 terhadap laporan tindak pidana penggelapan terhadap pelaku yang menguasai objek sertifikat sebelumnya telah sesuai dengan Hukum acara pidana dan doktrin hukum sebab sifat tindak pidana penggelapan itu sendiri adalah delik yang dapat diselesaikan melalui jalur mediasi penal sebagaimana tertuang dalam Surat Edaran Kapolri Nomor 14 Tahun 2008 tentang Alternatif Dispute of Resolution. Menurut Muladi model konsensus yang dianggap menimbulkan konflik baru harus diganti dengan model asensus, karena dialog antara yang berselisih untuk menyelesaikan masalahnya, adalah langkah yang sangat positif. Dengan konsep ini muncul istilah ADR yang dalam hal-hal tertentu menurut Muladi lebih memenuhi tuntutan keadilan dan efisien. ADR ini merupakan bagian dari konsep restorative justice yang menempatkan peradilan pada posisi mediator ${ }^{10}$;

5. Dalam sistem peradilan pidana penyidik dan penuntut umum tunduk terhadap setiap putusan pengadilan sebagai lembaga yudisial yang bertugas menyelenggarakan kekuasaan kehakiman sebagaimana dimaksud dalam Mahkamah Konstitusi ("MK") dan Mahkamah Agung ("MA") merupakan lembaga yang diberikan kewenangan untuk menyelenggarakan kekuasaan kehakiman berdasarkan Pasal 24 ayat (2) Undang-Undang Dasar Negara Republik Indonesia Tahun 1945 dan undang-undang nomor 48 tahun 2009 tentang kekuasaan kehakiman.

Berdasarkan uraian di atas dapat disimpulkan bahwa secara teoritis dengan mengacu pada konstruksi hukum pidana tindakan penyidik menyerahkan aset sitaan ke pengadilan karena Surat Nomor: W23.UI/1080/HT/VI/2017 yang dikeluarkan pengadilan tentang perihal tindak lanjut penyelesaian pelaksanaan putusan eksekusi memerintahkan penyidik untuk

10 Muladi, Hak Asasi Manusia, Politik dan Sistem Peradilan Pidana, Semarang: Badan Penerbit Universitas Diponegoro, 1997, hlm. 67. 
menyerahkan sertifikat tersebut kepada pengadilan tidak terpenuhi unsur kesalahan yang diketahui dan dikehendaki oleh penyidik sehingga tidak dapat dimintakan pertanggungjawaban pidana. Selain itu dalam konstruksi aturan hukum pasal 415 KUHP dan 374 KUHP tidak terpenuhi unsur Penggelapan dalam jabatan karena yang dapat menguntungkan penyidik dan orang lain atas tindakan penyerahan sertifikat tersebut sehingga tidak dapat memenuhi unsur objektif dari pasal tersebut di atas. Oleh sebab itu menurut teori ajaran kesalahan dan pertanggungjawaban pidana apabila tidak terpenuhi salah satu unsur pasal yang dituntutkan maka tidak dapat diterapkan pasal tersebut.

Menurut penulis bahwa dalam konstruksi teori hukum dan ajaran hukum pidana serta aturan hukum maka sepatutnya laporan penggelapan terdapat jabatan yang disangkakan kepada penyidik Reskrim Kendari oleh pelapor Muhamad Andi Nurdin yang telah diproses oleh PROPAM POLDA SULTRA dan OBUSMANT perlu dihentikan demi keadilan dan kepastian hukum bagi terlapor penyidik Reskrim Polres Kendari. Untuk itu, perlu diterbitkan Surat Perintah Penghentian Penyidikan (SP3) . Alasan Penerbitan SP3 telah terpenuhi sebagaimana yang diatur dalam pasal 109 ayat (2) KUHAP yang secara limitatif menjelaskan sebagai berikut, yaitu:

1. Tidak diperoleh bukti yang cukup, yaitu apabila penyidik tidak memperoleh cukup bukti untuk menuntut tersangka atau bukti yang diperoleh penyidik tidak memadai untuk membuktikan kesalahan tersangka;

2. Peristiwa yang disangkakan bukan merupakan tindak Pidana;

3. Penghentian penyidikan demi hukum. Alasan ini dapat dipakai apabila ada alasanalasan hapusnya hak menuntut dan hilangnya hak menjalankan pidana, yaitu antara lain karena nebis in idem, tersangka meninggal dunia, atau karena perkara pidana telah kedaluwarsa.

\section{Perlindungan yang Berkepastian Hukum Bagi Penyidik dalam Pelaksanaan Tugas dan Wewenangnya dalam Penyitaan Atas Tindakan Penyerahan Sertifikat Sitaan ke Pengadilan}

Konsep perlindungan hukum dimaknai sebagai suatu bentuk pelayanan yang wajib dilaksanakan aparat penegak hukum untuk memberikan rasa aman, baik fisik maupun mental, kepada korban dan sanksi dari ancaman, gangguan, teror, dan kekerasan dari pihak mana pun yang dijalankan dengan proses litigasi maupun non litigasi. Perlindungan hukum adalah suatu perlindungan yang diberikan terhadap subyek hukum baik secara perorangan maupun badan 
hukum yang bersifat preventif maupun yang bersifat represif, baik yang tertulis maupun tidak tertulis. perlindungan hukum yang berkapasitas hukum dalam penyitaan bagi penyidik sebagai jaminan perlindungan yang memiliki kekuatan hukum yang mengikat yang dibuat oleh penguasa karena penyidik adalah alat penguasa dibidang penegakan hukum. Oleh sebab itu negara berkewajiban memberikan kepastian hukum yang merupakan hak dari penyidik dalam melakukan dan menyelenggarakan penegakan hukum di bidang peradilan pidana. Penyidik sebagai elemen dasar yang bertugas melakukan tindakan hukum pencegahan, perlindungan, pemenuhan, pemajuan dan penegakkan hukum dibidang penyitaan maka diperlukan aturan hukum yang berkepastian sebagai dasar perlindungan kepadanya. Namun jika hak perlindungan tidak dijamin kepada penyidik secara tegas di dalam peraturan hukum di bidang penyitaan maka penegak hukum yang dilakukan penyidik akan selalu berhadapan dengan hukum bagaikan bumerang dalam pelaksanaan tugas dan wewenang dibidang hukum dan hal tersebut akan menghambat jalannya penegakkan hukum dibidang struktur juga substansi hukum tidak mengandung kepastian hukum bagi penyidik dalam penyitaan.

Dalam kaitannya dengan Penyitaan aset sangat berkaitan dengan sistem peradilan. Berkaitan dengan sistem peradilan, tidak mungkin dipisahkan dari sistem hukum yang berlaku di sebuah negara. Hal ini adalah suatu kewajaran sebab sistem peradilan adalah sebagai salah satu sub sistem dari sistem hukum-hukum nasional secara keseluruhan yang dianut oleh suatu negara. Oleh sebab itu, setiap negara di dunia ini mempunyai sistem peradilan yang meskipun secara garis besar hampir sama namun memiliki karakter tersendiri yang disesuaikan dengan kondisi sosial masyarakat, budaya dan politik yang dianut ${ }^{11}$.

Secara sederhana sistem peradilan, dalam hal ini adalah sistem peradilan pidana adalah proses yang dilakukan oleh negara terhadap orang-orang yang melanggar hukum pidana. Proses itu dimulai dari kepolisian, kejaksaan dan akhirnya pengadilan. Sebagaimana yang diungkapkan Carvadino dan Dignan bahwa sistem peradilan pidana adalah "A term covering all those institution which respond officially to the commision of offences, notably the police, prosecution authorities and the court"12. Dengan kata lain, sistem peradilan pidana ini tidak hanya mencakup satu institusi tetapi berkaitan erat dengan beberapa institusi negara yang menurut Feeney pekerjaan aparat penegak hukum yang satu akan memberikan dampak dan

11 Eddy, OS. Hiariej, “Criminal Justice System in Indonesia, Between Theory and Reality”, Asian Law Review Vol. 2, No. 2 December 2005, Korean Legislation Recearch Institute, hlm. 25.

12 Michael Cavadino and James Dignan, The Penal Sistem An Indtroduction, London: SAGE Publication Ltd, 1997, hlm. 24. 
beban kerja kepada aparat penegak hukum yang lain ${ }^{13}$.

Hebert L. Packer dalam The Limits of the Criminal Sanction mengatakan bahwa para penegak hukum dalam sistem peradilan pidana adalah integrated criminal justice system yang tidak dapat dipisah-pisahkan. Artinya, antara tugas penegak hukum yang satu dengan lainnya saling berkaitan. Packer selanjutnya memperkenalkan dua model dalam sistem peradilan pidana yaitu crime control model dan due process model. Crime control model memiliki karakteristik efisiensi, mengutamakan kecepatan dan presumtion of innocent sehingga peranan penasihat hukum amat penting sekali dengan tujuan jangan sampai menghukum orang yang tidak bersalah. Model ini diibaratkan seperti orang yang sedang melakukan lari gawang. Kedua model tersebut ada nilai-nilai yang bersaing tetapi tidak berlawanan ${ }^{14}$.

Dalam perkembangan selanjutnya, sistem peradilan pidana dengan model due process mendominasi sistem peradilan pidana di berbagai belahan dunia karena dianggap telah menjamin hak asasi manusia, lebih transparan dan dapat dipertanggungjawabkan. Konsekuensi selanjutnya instrumen hukum internasional yang berkaitan dengan pencegahan dan pemberantasan suatu kejahatan menggunakan due process of law dalam sistem beracaranya. Dalam konteks yang demikian haruslah diingat bahwa pengembalian aset akan berhadapan dengan lebih dari satu sistem hukum.

Oleh sebab itu dalam sistem peradilan yang digunakan adalah model yang diterima secara universal, yakni due process of law. Sementara dalam sistem peradilan perdata pada hakikatnya memiliki karakteristik yang sama hampir seluruh di dunia bahwa inisiatif beracara datang dari para pihak, hakim bersifat pasif dan kebenaran yang dicari adalah kebenaran formal yang terikat pada alat bukti yang sah menurut undang-undang.

Dari pengertian di atas, maka dapat disimpulkan sebagai suatu legal action atau upaya hukum dari seseorang untuk mengklaim kepemilikan atas suatu benda. Langkah semacam ini dapat dilakukan terhadap benda bergerak maupun benda tidak bergerak termasuk sertifikat. Dalam sistem hukum Indonesia, khususnya terhadap benda bergerak, kepemilikan dilandaskan pada penguasaan (bezitter) , sehingga tindakan mengklaim kepemilikan dilakukan dengan mengalihkan penguasaan dan di antaranya bila dipandang perlu dilakukan dengan langkah hukum atau legal action yaitu "menggugat" pihak lain yang menguasai benda tersebut. Sedangkan terhadap benda bergerak yang tidak bertuan (res nullius) , secara hukum ditetapkan

13 University Of Leicester, Modul 5, “Issues In The Criminal Justice Process”, Leicester: Scarman Center, University Of Leicester, 1998, hlm. 24.

14 L. Packer, The Limits Of The Criminal Sanction, Oxford: Oxford University Press, 1968, hlm. 149. 
sebagai dikuasai oleh negara.

Sementara untuk benda tidak bergerak, kepemilikan sertifikat sitaan harus dibuktikan dengan de jure, karenanya kepemilikan selalu didasarkan adanya bukti yang diakui secara hukum. Terhadap benda tidak bergerak seperti halnya tanah, pada dasarnya negara menguasainya kecuali terhadap tanah-tanah yang secara hukum dapat dibuktikan adanya hak atas tanah tersebut. Kendatipun lembaga tidak dikenal di dalam sistem hukum Indonesia yang merupakan sistem hukum sipil, tidak berarti lembaga semacam ini tidak dapat di integrasikan ke dalam sistem hukum sipil.

Hal lain yang juga penting untuk dipahami adalah penguasaan setiap benda yang termasuk dalam definisi aset kejahatan merupakan penguasaan yang bersifat melawan hukum. Terhadap hal ini kita dapat berpedoman pada prinsip "the fruit of the poissness tree" yang mana setiap hasil dari tindakan yang ilegal haruslah dipandang sebagai ilegal. Konsekuensi dari pandangan ini, maka upaya pengembaliannya tidaklah sama seperti upaya pengalihan aset dalam hukum perdata, karena sesungguhnya pengembalian aset kejahatan merupakan langkah hukum yang bersifat publik.

Kendatipun negara diberikan kewenangan tersebut, namun dalam melaksanakannya tetap dibutuhkan keterlibatan institusi pengadilan guna memberikan pengesahan yang dibutuhkan sebagai alas hukum dalam penyitaan aset. Selain itu pengadilan juga dibutuhkan sebagai tindakan pengawasan agar kewenangan penyitaan aset yang disalahgunakan serta aset yang telah dimenangkan dalam perkara perdata. Berangkat dari pemikiran yang demikian, maka upaya pengembalian aset dan perampasan aset dapat dibenarkan selama sesuai dengan prosedur hukum yang berlaku di dalam sistem peradilan pidana.

Berdasarkan uraian tersebut di atas maka secara teoritis dan norma tindakan penyidik menyerahkan sertifikat kepada pengadilan adalah tindakan karena norma perintah yang melekat pada jabatan penyidik dalam pelaksanaan tugas penyitaan. Norma perintah tersebut mengandung dua makna yakni pertama, norma perintah untuk melakukan dan melaksanakan penyitaan yang di berikan undang-undang kepada penyidik dan yang kedua adalah norma perintah yang bermakna bahwa penyidik harus tunduk terhadap perintah kekuasaan kehakiman sebagaimana yang dimaksud di dalam undang-undang nomor 48 tahun 2009 tentang kekuasaan kehakiman hak ini di buktikan bahwa setiap tindakan penyitaan yang akan dilakukan oleh penyidik wajib melalui izin dari pengadilan begitu pula norma perintah pengembalian aset sitaan sertifikat juga harus melalui izin kepada pengadilan. Dasar pelaksanaan norma perintah tersebut telah dilaksanakan oleh penyidik meminta kepada 
pengadilan untuk melakukan penyitaan dan pengembalian melalui surat nomor: B/425/VI/2017 Reskrim. Secara teoritis dan norma dengan diterbitkannya surat nomor: B/425/VI/2017 Reskrim menujukan bahwa Satreskrim Kendari telah pelaksanaan norma perintah yang diwajibkan oleh undang-undang untuk menyampaikan segala pelaksanaan penyitaan kepada pengadilan.

\section{KESIMPULAN}

Berdasarkan hasil penelitian dan pembahasan yang telah diuraikan di atas, maka dapat ditarik kesimpulan yaitu penyerahan sertifikat sebagai aset sitaan penyidik kepada pengadilan yang berimplikasi sebagai tindak pidana penggelapan dalam jabatan bukan sebagai tindak pidana. Dalam konteks teori hukum unsur mengetahui dan menghendaki (willens en wetens) sebagai unsur kesengajaan atas kesalahan tidak terpenuhi sehingga tidak dapat dimintakan pertanggungjawaban pidana. Dalam Konteks aturan hukum Pasal 415 KUHP dan Pasal 374 KUHP juga tidak terpenuhi unsur objektif dari penggelapan yakni unsur menyalahgunakan jabatan yang merugikan orang lain karena penyerahan sertifikat kepada pengadilan sesuai dengan Surat Nomor: W23.UI/1080/HT/VI/2017 Perihal tindak lanjut penyelesaian pelaksanaan putusan eksekusi memerintahkan penyidik untuk menyerahkan sertifikat tersebut kepada pengadilan.

\section{Daftar Pustaka}

\section{Buku}

Cavadino, Michael and James Dignan, The Penal Sistem An Indtroduction, London: SAGE Publication Ltd, 1997.

Handrawan, Pencabutan Hak Politik dalam Pemidanaan Tindak Pidana Korupsi, Surabaya: Media Sahabat Cendekia, 2019.

Muladi, Hak Asasi Manusia, Politik dan Sistem Peradilan Pidana, Semarang: Badan Penerbit Universitas Diponegoro, 1997.

Packer, L., The Limits Of The Criminal Sanction, Oxford: Oxford University Press, 1968.

Prasetyo, Teguh, Hukum Pidana, Jakarta: RajaGrafindo Persada, 2014.

Purnomo, Bambang, Asas-Asas Hukum Pidana, Yogyakarta: Ghia Indonesia, 1994.

University Of Leicester, Modul 5, "Issues In The Criminal Justice Process", Leicester: Scarman Center, University Of Leicester, 1998. 


\section{Jurnal dan Makalah}

Haris, Oheo K., "Telaah Yuridis Penerapan Sanksi di Bawah Minimum Khusus pada Perkara Pidana Khusus", Jurnal Ius Constituendum, Volume 2, Nomor 2, 2017.

Hiariej, Eddy, OS., “Criminal Justice System in Indonesia, Between Theory and Reality”, Asian Law Review Vol. 2, No. 2 December 2005, Korean Legislation Recearch Institute.

Sumaidi, “Kajian Terhadap Penyitaan Sebagai Pemaksaan yang Dihalalkan oleh Hukum”, Jurnal Legaliatas: Jurnal Hukum. Vol. 8 Nomor 1 Tahun 2016.

\section{Peraturan Perundang-undangan}

Undang-Undang Nomor 1 Tahun 1946 tentang Peraturan Hukum Pidana jo. Undang-Undang Nomor 73 Tahun 1958 tentang Menyatakan Berlakunya Undang-Undang Nomor 1 Tahun 1946 tentang Peraturan Hukum Pidana untuk Seluruh Wilayah Republik Indonesia dan Mengubah Kitab Undang-Undang Hukum Pidana. (Lembaran Negara Tahun 1958 Nomor 127, Tambahan Lembaran Negara Republik Indonesia Nomor 1660) Undang-Undang Nomor 8 Tahun 1981 tentang Hukum Acara Pidana (Lembaran Negara Republik Indonesia Tahun 1981 Nomor 76, Tambahan Lembaran Negara Republik Indonesia Nomor 3258)

Undang-Undang Nomor 2 tahun 2002 Tentang Kepolisian Negara Republik Indonesia (Lembaran Negara Republik Indonesia Nomor 4168)

Undang-Undang Nomor 48 Tahun 2009 tentang Kekuasaan Kehakiman (Lembaran Negara Republik Indonesia Nomor 4168)

Peraturan Pemerintah Nomor 27 Tahun 1983 tentang Pelaksanaan Kitab Undang-Undang Hukum Acara Pidana (Lembaran Negara Republik Indonesia Tahun 1983 Nomor 36, Tambahan Lembaran Negara Republik Indonesia Nomor 3258) 